\title{
The Effect of the Intervention "Pramenopause Empowerment Model (PEM)" Based on Health Belief Against the Balanced Dietary Changes in the Control of Perimenopause Complaints in Pematangsiantar 2017
}

Dame Evalina Simangunsong ${ }^{1}$, Rika Subarniati Triyoga ${ }^{2}$, Muhammad Fidel Ganis Siregar ${ }^{3}$, Rahayu Lubis $^{4}$

${ }^{1}$ Department of Public Health University of North Sumatera, Medan

${ }^{2}$ Department of Public Health University of Airlangga, Surabaya

${ }^{3}$ Department of Obstetris \& Gynaecology of Faculty of Medicine University of North Sumatera, Medan

${ }^{4}$ Department of Public Health University of North Sumatera, Medan

\begin{abstract}
Overweight middle-aged at the age in addition to dealing with increased risk of cardiovascular and metabolic disease, also affects the quality of life and sexual function. Increase in weight the agency along with increasing age need to look out for, adepositas or obesity and disorders of carbohydrate metabolism. This can occur as a result of changes in hormone balance affects weight control. Empowerment of knowledge of eating patterns and intake in women pramenopause felt very necessary given the pattern of activity of the adult age group also food consumption behaviour that is not balanced. This type of research is quasi experiment with two design group pretest-posttest design with control group in two Sub involving women aged 40-45 years, 35 people on the intervention group and a control group of 35 people. Data analysis done to see the changes before and after the intervention and its effects on the patterns and intake of eating intervention group. Data on sports with univariate analysis, bivariate with Shapiro-Wilk, test t-test dependent. The results showed there is influence the granting of the intervention Pramenopause Empowerment-based Model of Health Belief Model before and after interventions against changes in eating patterns and intake $(p=0.006)$. Socialization pocket book and diary consumption patterns of eating in women's pramenopause empowerment is very to do so can improve healthier patterns of living in order to support the health and quality of life.
\end{abstract}

Keywords: Health Belief, Diet, Meal Frequency

\section{Background}

Hormonal changes during perimenopause substantially contribute to an increase in abdominal obesity that causes physical and psychological morbidity. Overweight middleaged age other than related to an increased risk of cardiovascular and metabolic disease, also affects the quality of life and sexual function. (1) Women that his weight go up are more likely to experience a decline in the quality of alive. Body Mass Index (BMI) is correlated with a higher score the higher of the menopausal symptoms. (2) The increase in body mass index (IMT) is associated with a decrease in health or relationship of obesity with chronic diseases and also changes in blood pressure.

The results of a study conducted in Zaria Nigeria, find women post-menopause more likely to be overweight (BMI means $25.96 \pm 0.53 \mathrm{~kg} / \mathrm{m} 2$ ) compared with premenopausal $(23.13 \pm 0.57 \mathrm{~kg} / \mathrm{m} 2)$. The menopausal women also have a higher waist circumference $(93.04 \pm 1.60 \mathrm{~cm})$ compared to women (premenopausal $78.87 \pm 1.30 \mathrm{~cm}$ ). Only $73.86 \%$ of menopausal women had a BMI of $25 \mathrm{~kg} / \mathrm{m}^{2}$ while the prevalence of central obesity is $79 \%$. There is a positive correlation and significantly between waist circumference and body mass index. (3) increase in weight as we get older need to look out for adepositas, or obesity and disorders of carbohydrate metabolism. This can occur as a result of changes in the balance of hormones that influence weight control. $^{4}$

It gives basic information about empowerment patterns and intake the based on feeding Health Belief, pramenopause is on a woman because any changes the metabolism of carbohydrates, fats and proteins that will suffered because of fluctuations in hormone and the existence of a trend pattern activity adult age groups that influence the behavior of consumption food that is not balanced. An increased risk of exposure to pollution and food insecure, the availability of a variety of fast food and ready sports and ignorance about nutrition for women who work outside the home. Age group of workers tends to be activity light or relax (sedentary life). Therefore attention to behavior balanced nutrition needs to be improved to achieve healthy living patterns, active and productive.

The principle of setting a balanced diet as the basis for setting eating patterns in women during perimenopause: i. a decrease in estrogen plays a major role in gaining weight; II. Therefore weight gain, women tend to do the diet behavior wrong (skipping meals and hunger); III. Behavioral diets wrong cause fluctuating blood sugar regulation irregular so 


\section{International Journal of Science and Research (IJSR) \\ ISSN (Online): 2319-7064}

Index Copernicus Value (2015): 78.96 | Impact Factor (2015): 6.391

the levels of glucose and insulin on high to circulate in the blood at one time.

Table 1: Recommended by the Number of Servings According to the adequacy of the energy for the age group 30-49 Years

\begin{tabular}{|c|c|}
\hline Foodstuffs. & Mature Women $30-49$ years $(2125 \mathrm{kal})$. \\
\hline Rice & 4,5 porsi \\
\hline Vegetables & 3 porsi \\
\hline Fruit & 5 porsi \\
\hline Tempe & 3 porsi \\
\hline Meat & 3 porsi \\
\hline Oil & 6 porsi \\
\hline Sugar & 2 porsi \\
\hline
\end{tabular}

(Source : Permenkes No 41/2014

Description:

1. Rice 1 porsi $=3 / 4$ glass $=100 \mathrm{gr}=175 \mathrm{kkal}$

2. Vegetable 1 porsi $=1$ glass $=100 \mathrm{gr}=25 \mathrm{kkal}$

3. Fruit 1 porsi $=1$ banana $=50 \mathrm{gr}=80 \mathrm{kkal}$

4. Tempe 1 porsi $=2$ cut medium $=50 \mathrm{gr}=80 \mathrm{kkal}$

5. Meat 1 porsi $=1$ cut medium $=35 \mathrm{gr}=50 \mathrm{kkal}$

6. Fish 1 porsi $=1 / 3$ piece $=45 \mathrm{gr}=50 \mathrm{kkal}$

7. Oil 1 porsi $=1 \mathrm{sdt}=5 \mathrm{gr}=50 \mathrm{kkal}$

8. Sugar $1 \mathrm{sdm}=20 \mathrm{gr}=50 \mathrm{kkal}$

9. Milk 1 porsi $=1$ glass $=200 \mathrm{gr}=50 \mathrm{kkal}$

10. Milk low fat 1 porsi $=4 \mathrm{sdm}=20 \mathrm{gr}=75 \mathrm{kkal}$

Health promotion in women pramenopause in the control of the perimenopause complaints will affect them to this day have not been getting attention means. Variety identification of complaints have been experienced during the period of perimenopause and menopause was overcome with various alternatives of action in reducing the perceived grievances. The awarding of the promotif effort or knowledge in the period of perimenopause is felt less effective or it's too late. It needs a proper preventive efforts to prepare for a woman live healthy and self-sufficient through the period of perimenopause especially about the changes the metabolism of fat, protein and carbohydrates that can affect the increase in weight as a result of fluctuation of the hormone estrogen. Prevention efforts by providing health information in avoid risky behavior in women pramenopause need to be emphasized. The maintenance of healthy eating patterns, maintaining the balance of weight and height, the addition of the Calsium needs each day and physical activity regularly need to be socialized.

The approach through the empowerment of women pramenopause with Pramenopause Empowerment Model (PEM) that contains information about the change of knowledge the metabolism of carbohydrates, proteins and fats due to the decrease in estrogen, which will be experienced by women in the reproductive period, the threat of disease due to increased weight, healthy life patterns in the form of regularity of eating and a balanced diet in an effort to gain weight the ideal can be given before the period of perimenopause.

This is done by providing empowerment pocket book "Achieves Health Until old age "and leaflets" Menopause "containing balanced food information age group 30-49 years and the frequency of a good meal per day (breakfast, snack, lunch, snack, dinner and snack).

\section{Research Issues}

Is there any influence of the intervention "Pramenopause Empowerment Model (PEM)" to change the pattern and intake of balanced eating in an attempt control complaint perimenopause in Pematangsiantar in 2017.

The Purpose of the Research.

Analyzing the difference of eating patterns and feeding intake of women pramenopause before and after application of the Pramenopause Empowerment Model (PEM) and treatment group group controls.

\section{Material and Methods}

This Type of Research

The type of research used quasi experimental design are two group pretest-posttest design with control group. ${ }^{6}$

\section{Location of Research}

Research done in the two subdistricts (kecamatan), Subdistricts Kahean (for the control group) and Subdistricts Tomuan (intervention group).

The time of the study.

Research carried out for 3 months with 3 times the intervention, has done since November to January 20162017.

\section{Population and sample}

The population in this research is pramenopause-old woman 40-45 living in the town of Pematangsiantar. The method of withdrawal sample done with technical purposive sampling with inclusion criteria and exclusion.

The number of samples obtained as many as 30 people and to avoid samples dropped out or lost to follow up, then great sample maximum 35 people were taken to the intervention group and 35 people to the control group (1:1).

\section{Research Flowchart}

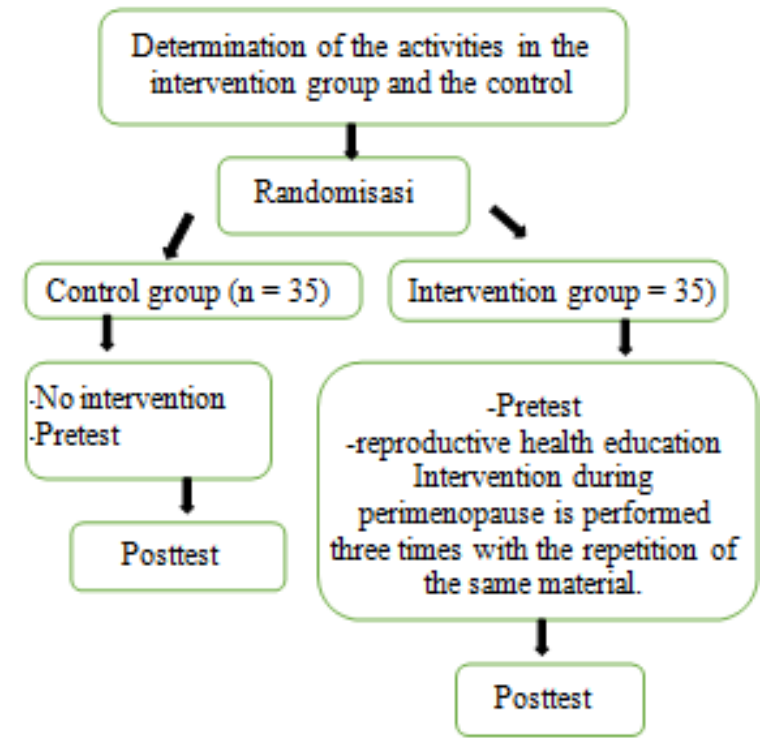

Figure 1: Research flowchart 


\section{International Journal of Science and Research (IJSR) \\ ISSN (Online): 2319-7064}

Index Copernicus Value (2015): 78.96 | Impact Factor (2015): 6.391

\section{Stages of Intervention}

\begin{tabular}{|c|c|}
\hline Stage & Description \\
\hline $\mathrm{I}$ & A woman's reproductive life cycle explains. \\
\hline II & $\begin{array}{l}\text { The issue of reproductive health in the period of } \\
\text { perimenopause. }\end{array}$ \\
\hline III & $\begin{array}{l}\text { Potential health problems which threaten the survival of } \\
\text { with respect to the reduced and the loss of Estrogen. } \\
\text { Healthy living patterns with patterns and intake of } \\
\text { balanced eating, and frequency eating regularly by } \\
\text { applying the filling a diary as a alternative efforts keep the } \\
\text { balance weight, in reducing the impact of the drop in } \\
\text { estrogen. }\end{array}$ \\
\hline
\end{tabular}

\section{The Ethics of Research}

Implementation research has gained the approval of recommendations Health Research Ethics Committee of the Faculty of nursing University of North Sumatra (No. 1058/X/SP/2016).

\section{Analysis of the data}

The data were analyzed by using SPSS version 21, characteristics the respondents are presented in the form of a table of frequency distribution and influence intervention Pramenopause Empowerment Modeel (PEM), health belief and knowledge are analyzed with using independent $t$ test.

\section{Research Results}

Table 1: Test of Homogenity Characteristics of Respondents

\begin{tabular}{|c|c|c|c|c|c|}
\hline \multirow[t]{2}{*}{ Karakteristik Responden } & \multicolumn{2}{|c|}{ Intervention } & \multicolumn{2}{|c|}{ Control } & \multirow[b]{2}{*}{$\mathrm{p}$} \\
\hline & n (35) & $\%$ & n (35) & $\%$ & \\
\hline \multicolumn{6}{|l|}{ Age } \\
\hline $40-42$ years & 21 & 60,0 & 26 & 74,3 & \multirow{2}{*}{0,262} \\
\hline $43-45$ years & 14 & 40,0 & 9 & 25,7 & \\
\hline \multicolumn{6}{|l|}{ Education Level } \\
\hline Low (SD,SMP) & 9 & 25,7 & 4 & 11,4 & \multirow{2}{*}{1,000} \\
\hline High (SLTA D3,S1,S2) & 26 & 74,3 & 31 & 88,6 & \\
\hline \multicolumn{6}{|l|}{ Occupation } \\
\hline Unemployed & 14 & 40,0 & 17 & 48,6 & \multirow{2}{*}{0,714} \\
\hline Employed & 21 & 60.0 & 18 & 51,4 & \\
\hline \multicolumn{6}{|l|}{ Menstruation cycle } \\
\hline Normal & 21 & 60,0 & 23 & 65,7 & \multirow{2}{*}{1,000} \\
\hline Abnormal & 14 & 40,0 & 12 & 34,3 & \\
\hline \multicolumn{6}{|l|}{ Married Age } \\
\hline$\leq 20$ years & 2 & 5,7 & 3 & 8,6 & \multirow[t]{2}{*}{1,000} \\
\hline$>20$ years & 33 & 94,3 & 32 & 91,4 & \\
\hline Parity & & & & & 0,458 \\
\hline$\leq 2$ & 10 & 28,6 & 15 & 42,9 & \multirow{5}{*}{0,902} \\
\hline $\begin{array}{c}>2 \\
\end{array}$ & 25 & 71,4 & 20 & 57,1 & \\
\hline $\begin{array}{c}\text { Body Mas Index } \\
\text { Normal }\end{array}$ & 18 & 51,4 & 19 & 54,3 & \\
\hline Obese & 11 & 31,4 & 8 & 22,9 & \\
\hline Obesity & 6 & 17,1 & 8 & 26,6 & \\
\hline
\end{tabular}

$P^{*}:$ Chi Square test

Source ; primary data 2017
Table 4: Frequency Distribution of The Difference Increased Variable Category Health Belief After Application of PEM In The Intervention and Control Group Women

Pramenopause in Pematangsiantar 2016-2017

\begin{tabular}{|c|c|c|c|c|c|c|c|}
\hline Kelompok & \multirow{2}{*}{ HBM } & \multicolumn{2}{|c|}{ Pretest } & \multicolumn{2}{|c|}{ Posttest } & \multirow{2}{*}{ d } & \multirow{2}{*}{ P* } \\
\cline { 3 - 7 } & & $\mathrm{n}$ & $\%$ & $\mathrm{n}$ & $\%$ & & \\
\hline Intervention & High & 9 & 25,7 & 24 & 66,6 & 15 & \multirow{3}{*}{} \\
\cline { 2 - 7 } & Low & 26 & 74,3 & 11 & 31,4 & -15 & $<0,001$ \\
\hline Control & High & 5 & 5,0 & 11 & 31,4 & 6 & \multirow{2}{*}{0,070} \\
\cline { 2 - 6 } & Low & 0 & 30,0 & 24 & 68,6 & -6 & 0,070 \\
\hline
\end{tabular}

$p^{*} ;$ McNemar test

Sumber : primary data 2017

Table 5: Frequency Distribution of the Difference Increased Variable Patterns and Category Intake Eat After Application of PEM In The Intervention and Control

Women's Pramenopause in Pematangsiantar 2016-2017

\begin{tabular}{|c|c|c|c|c|c|c|c|}
\hline \multirow[t]{2}{*}{ Kelompok } & \multirow{2}{*}{$\begin{array}{c}\text { Pola dan } \\
\text { Asupan Makan }\end{array}$} & \multicolumn{2}{|c|}{ Pretest } & \multicolumn{2}{|c|}{ Posttest } & \multirow[t]{2}{*}{ d } & \\
\hline & & $\mathrm{n}$ & $\%$ & $\mathrm{n}$ & $\%$ & & \\
\hline \multirow[t]{2}{*}{ Intervention } & Enough & 12 & 34,3 & 22 & 62,9 & 10 & \multirow[b]{2}{*}{0,006} \\
\hline & & 23 & 65,7 & 13 & 37,1 & -10 & \\
\hline \multirow[t]{2}{*}{ Control } & Enough & 8 & 22,9 & 14 & 40,0 & 6 & \multirow[b]{2}{*}{0,070} \\
\hline & More & 27 & 77 & 21 & 60,0 & -6 & \\
\hline
\end{tabular}

$p^{*} ;$ McNemar test

Sumber : primary data 2017

Table 6: The Difference in the Increase of the Mean Score Health Belief Model, pattern and intake of meals, physical activity

The intervention and control group of women

Pramenopause in Pematangsiantar 2016-2017

\begin{tabular}{|c|c|c|c|c|c|c|}
\hline Variabel/ & \multicolumn{2}{|c|}{ Mean } & Perbedaan & SD & $\begin{array}{c}\text { Nilai } \\
\mathrm{p}\end{array}$ & $\begin{array}{c}\text { Uji t- } \\
\text { Dependent }\end{array}$ \\
\cline { 2 - 7 } & $\begin{array}{c}\text { Pre } \\
\text { test }\end{array}$ & $\begin{array}{c}\text { Post } \\
\text { test }\end{array}$ & Mean & & & \\
\hline $\begin{array}{c}\text { Pola dan } \\
\text { Asupan Makan }\end{array}$ & & & & & & \\
\hline Intervention & 0,66 & 0,037 & 0,286 & 0,667 & 0,016 & 2,533 \\
\hline Control & 0,77 & 0,60 & 0,171 & 0,435 & 0,059 & 2,240 \\
\hline$H B M$ & & & & & & \\
\hline Intervention & 50,29 & 77,77 & 18,486 & 10,615 & $<0,001$ & 10,303 \\
\hline Control & 54,23 & 54,94 &, 714 & 2,865 & 0,149 & 1,475 \\
\hline
\end{tabular}

\section{The Discussion}

Influence of intervention of Pramenopause Empowerment Model against knowledge of the patterns and intake eat

Balanced nutrition is the composition of foods that contain nutrients in the type and number of corresponding to the needs of the body with pay attention to the principle of diversity or variety of food, physical activity, hygiene and ideal body weight or Body Mass Index (BMI). ${ }^{7}$ Socialization about the pattern and a balanced food intake and regular very need to remember the trend increased weight because of changes in the metabolism of carbohydrates, proteins and fats. Because of the weight gain, women tend to do the diet behavior (skip meals).

The occurrence of changes in metabolism of carbohydrates, proteins and fats result fluctuation of hormones in women. A decrease in estrogen plays a major role in weight gain. This can occur because the body is trying looking for another source of estrogen. Fat cells can produce estrogen so your 


\section{International Journal of Science and Research (IJSR) \\ ISSN (Online): 2319-7064}

Index Copernicus Value (2015): 78.96 | Impact Factor (2015): 6.391

body work harder to convert calories into fat to raise estrogen levels. But fat cells do not burn calories as well as muscle cells and this is what triggers weight gain. ${ }^{4}$
The picture below shows the change in frequency of feeding group the intervention of frequency changed be irregular meal frequency eating regularly after a given intervention.

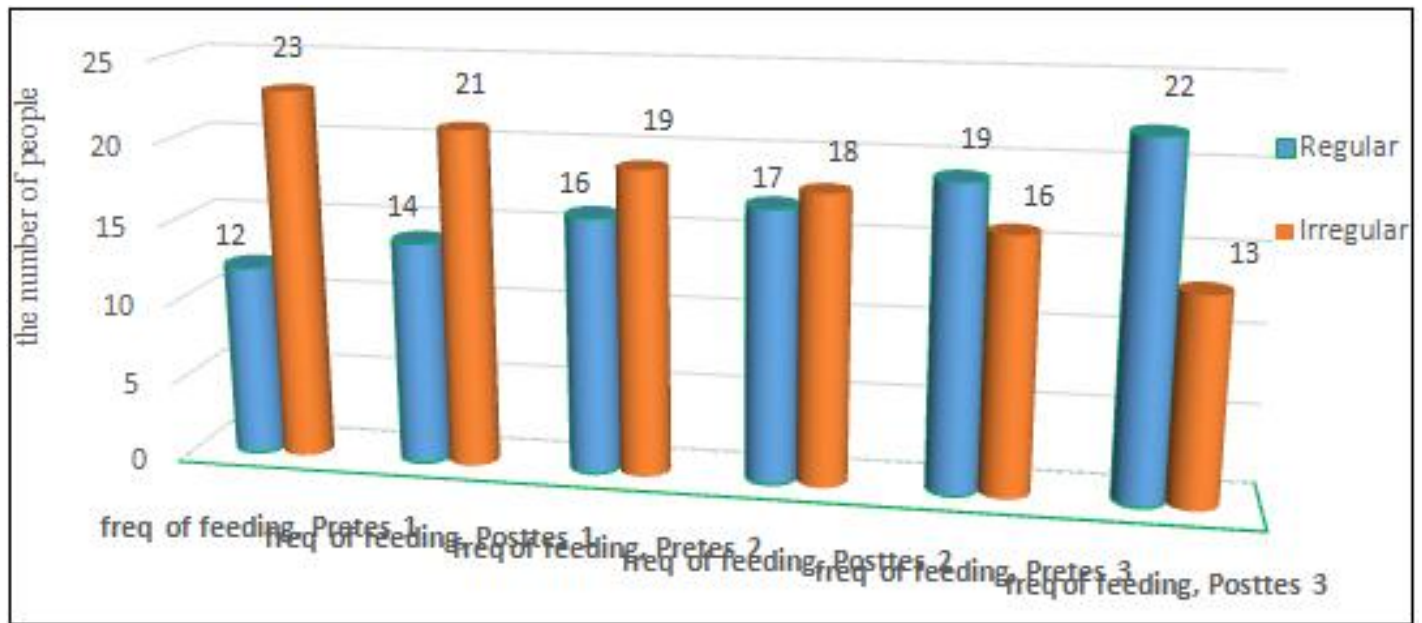

Figure 1: Diagram Bar Changes the frequency of Eating Women Pramenopause on Intervention Group

In table 4 , it can be seen that there is an increase in the frequency of eating regularly, after the intervention of PEM significantly $(p=0.006)$ and there the difference in the increase in the average diet score (the frequency of eating) regularly on measuring pretest and postest on group interventions in significant where the value $\mathrm{p}=0.016(\mathrm{p}<0.05)$.

Pramenopaue empowerment-based Health Belief model, capable of changing the perception of the individual against the vulnerability is exposed to a disease (perceived susceptibility). Vulnerability refers to beliefs about the possibility of a person to be exposed to disease. 8 this Model predicts pramenopause that women are more likely to adhere to a healthy lifestyle changes if they are vulnerable in the long-term impact of a deficiency or loss of estrogen in the body. Perceptions of the seriousness of (perceived severity), this refers to the feeling of woman in pramenopause assess how serious the condition is a health problem that will occur and the consequences brought about by health problems when left not prevented or treated. ${ }^{8,9}$

The perceived benefits of perception occurs when a person perceives vulnerable for a serious health condition, and the perception cause a change in behavior that would be affected by the conviction someone about the perceived benefits of various actions prevention. The perceived barriers of perception refers to the aspects of the negative and contradictory to conduct an act of prevention. ${ }^{9}$ Health Belief is a cognitive model which means that individual behavior is influenced cognitive processes in himself. The cognitive process is influenced by several factors such as expressed by many previous researchers such as demographic variables, sociopsicologis, and characteristics of structural variables.

The structural variables that is knowledge and experience of the problems will be encountered. Information about nutrition balanced in this intervention is explained in woman pramenopause about a balanced food intake on the age of 39-49 years in accordance with a balanced Nutritional Guidelines, Permenkes No. 41/2014 and the frequency of eating regularly in order to avoid increasing the excess weight. The granting of this information is done by providing nutrition education as contained in the pocket book coupled with inform the importance of consuming materials a meal containing Phytoestrogens and seeds that can be adding to the already diminished estrogen produced by the body. Besides the intake of Calcium-rich foods also introduced following with a rate of households that are useful also to keep bone density.

The granting of this information is also followed by practice how take the foodstuffs consumed daily and demonstration the manufacture of soy milk. This activity is done with three repetitions, with the hope of giving of information and demonstration of optimal and leave messages that are useful in live out his days with this self-supporting until entering perimenopause and raring to go with a sense of comfort. Monitoring the implementation of intake feeding on these respondents also followed by conducting home visits two weeks after the intervention is carried out.

Researcher and team assess daily consumption of respondents with correct diary intake patterns and eating have been distributed previously and at the time of the visit also conducted discussions about various things that are misunderstood about the interventions that have been made. This intervention is also emphasize in addition to notice patterns and intake of balanced eating, the activities of physical activity on a regular basis also needs to be done considering the both of these are highly related. 


\section{International Journal of Science and Research (IJSR) \\ ISSN (Online): 2319-7064}

Index Copernicus Value (2015): 78.96 | Impact Factor (2015): 6.391

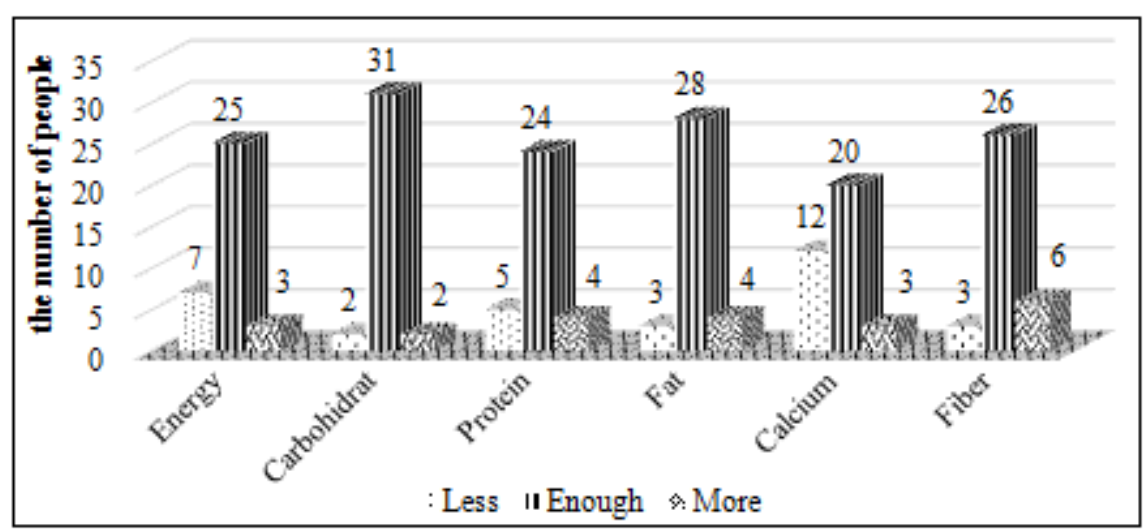

Figure 2: Diagram Bar Intake Eating Women Pramenopause in Intervention Group (Posttest)

Some of the results of the study showed that the low and declining physical activity is the most responsible factor for the occurrence of obesity. Decreased or increased physical activity and lifestyles sedentarian (less motion) has an important role in the increase in weight and the onset of obesity. Sedentary behavior is an activity that does not increase energy needs go beyond the level breaks, so the energy emitted from the body amounted to little. ${ }^{10}$

Frequency distribution of body mass index (IMT) in the intervention group as broken down in table 4.3 can be seen as much as $31.4 \%$ already be at the IMT and $17.1 \%$ classified as obese on obesity. The eating pattern frequency distribution (frequency of feeding) woman pramenopause the intervention group after being given an intervention changes towards the regular with the frequency of eating 5-6 times (3 times, and 2-3 times snack). The frequency of eating a regular or proper eating habits and increase activity can boost your metabolism. The frequency of eating regular blood sugar could stabilize because of a surge in blood sugar can affect the increase in weight. ${ }^{4}$

Nutrisurvei analysis of the composition of the food in the intervention group on pretes I, can be seen in Figure 2, the frequency distribution of the number of the adequacy Energy (RDA Energy), adequacy in carbohydrates (RDA Carbohydrates), adequacy of protein (RDA Protein), the adequacy of fat (RDA Fat), adequacy of calcium (RDA calcium) and the numbers are still at fiber adequacy categories less and more than nutritional adequacy figure age group 30-49 years. Analysis of nutrisurvei on 3rd posttes, frequency distribution of food composition that adequacy is assessed already been at good enough or category (80-110\% RDA).

Given the multitude of problems that arise when a woman do not understand the importance of eating a balanced diet and a regular coupled with the impact of the drop in estrogen in the body, that makes the body increasingly weigh up to obesity then this should be a concern given the increased weight will a risky result in various diseases as a generative various studies presented earlier in women perimenopause.

Research conducted in assessing the determinants of the incidence of hypertension on the population of women of perimenopause. The incidence of hypertension in women peri and post menopausal associated with increased body weight even when the effects of many other determinants, such as initial weight, physical activity and the use of Hormone Replacement Therapy (HRT), which be taken into account. ${ }^{11}$ Therefore prevent weight gain with how to diet and exercise is very important in the age of perimenopause..

Statement of The International Menopause Society, hormonal changes that occurs in menopausal women contribute to the improvement of the Central abdominal obesity that would interfere with the physical or psychological health. ${ }^{3}$ There is strong evidence that estrogen hormone therapy would prevent changes due to menopause on body fat distribution and impact her metabolism. ${ }^{9}$ A good understanding of the relationship between the increase in weight, menopause and body fat will help take positive steps toward improvement of pattern and quality of life. Excess weight can be lead to an increased risk of heart disease, hypertension, diabetes, stop breathing in sleep, cancer, osteoarthritis and mental health problems. ${ }^{12}$

Dietary changes (frequency of eating), woman pramenopause After the granting of health education information intake of balanced eating rich whole grains as well as a regular meal frequency by using media pocket book, showed a difference in eating patterns with the frequency of eating regularly, before and after treatment. Intervention This diet emphasizes the principle of balanced eating pattern settings, because the hormone estrogen fluctuations will cause changes the metabolism of carbohydrates, proteins and fats resulting in weight gain. This can occur because the body, trying to find the source of estrogen another. Fat cells produce estrogen so that the body can work more hard to convert calories into fat to raise estrogen levels. But fat cells do not burn calories as well as muscle cells and this is what triggers weight gain. ${ }^{4}$ Because of the weight gain, women tend to do the wrong diet behaviors skipping meals and hunger). The wrong diet behavior fluctuating blood sugar regulation causes irregular so that the levels of glucose and insulin on high to circulate in the blood.

Increasing blood insulin reduced the ability of the body burn fat. The risk of obesity in women increases along with age. When menopausal women experience a change of body fat especially in the abdomen compared with the lower part of the body as is often experienced by young women. Excess abdominal fat is closely related to obesity and other conditions for example, heart disease. ${ }^{3,13,14}$ A good understanding of the relationship between the increase in 


\section{International Journal of Science and Research (IJSR) \\ ISSN (Online): 2319-7064}

Index Copernicus Value (2015): 78.96 | Impact Factor (2015): 6.391

weight, menopause and body fat will help take positive steps toward improvement of pattern and quality of life of a woman. Excess weight the Agency can lead to an increased risk of heart disease, hypertension, diabetes, stop breathing in sleep, cancer, osteoarthritis and problems mental health. ${ }^{3,12}$ Therefore, a woman need to be aware the importance of the efforts of prevention rather than treatment and keep keep fitness and avoid excess weight after menopause.

Research conducted to know the body mass index on menopausal symptoms in menopausal women in Turkey, found that although somato-vegetative complaints, psychological and urogenital symptoms can be addressed with physical activity, and stabilize the body mass index. The results of this research are recommended for women who don't want to use therapy pharmacological treatment as symptoms of menopause can use alternative handling conventionally in addressing complaints perimenopause such as regular physical activity and maintaining patterns intake eat in keeping the increase in weight. ${ }^{15}$

Stop the wrong diet behaviors such as skipping meals, It turns out that can slow down your metabolism and trigger mechanism the body's defense against hunger. The results of the interviews that have been conducted on the implementation of the first intervention, there are as many as 20 people respondents who always skipped breakfast and eat at night every day. Various reasons like it's too late towards the workplace, yet feels hungry makes these women miss time the breakfast, and the reason fear fat, still full because there are eating snack in the late afternoon, causing the dinner also missed. This situation needs to change immediately, regular eating patterns are always being reminded every performed mentoring and intervention efforts, even reminded to always fill the diary intake patterns and eat during the intervention takes place. Hope in the future by implementing a regular pattern and has been familiar as early as possible the next then it can become a habit that rub off on the respondent.

Self defense mechanism the body fight hunger will arise when the body does not get the required calorie intake per day. A less caloric intake, under 1000 calories per day for two days will trigger mechanism. The body automatically reduces calorie burning by saving a little bit of calories obtained. This process creates a daily body metabolic rate slowdown (Daily Metabolic Rate $=$ DMR). If you are in a State of metabolism, it will be impossible to successfully lose weight and burn fat. ${ }^{4}$

Attention to the regulation of blood sugar are also noteworthy in an attempt to control the buildup of fat and increase in weight due to a decrease in estrogen in the body. The journal Menopause 2010 cited by 2014 Harpaz, suggested the rise in blood sugar causes excess insulin in the blood so that it can reduce the body's ability to use the fat as energy effective and when this takes place then the efforts of the body in burning fat and losing weight will also be reduced. The rise in blood sugar that triggers a rise in levels of insulin blood need to be avoided by: skip meals or there is the long periods between meals, eating a meal in the amount of great in all eating, excess intake of simple sugars (> $10 \mathrm{gr}$. per servings), two intake of carbohydrates in one dish. If the above cannot be avoided then insulin and blood sugar will rise and prevent the body utilizes fats and lose weight.

A woman's body that are experiencing perimenopause complaints because of the estrogen production from the ovaries decreases will be trying to find a second source estrogen in the body such as body fat, the skin. The tendency of the increased weight can be controlled by increasing the metabolism and this situation can be achieved in two ways: nutrition right (the right eating habits) and increasing activity.

Effects of termogenik food (thermogenic effet of food = TEF) can be used as a body in the use of calories to break down food It receives. The number of calories used (and how fast use it), this is based on the frequency of feeding, food quantity and quality of food. A balanced meal intake and diet a regular will create termogenik effects of food, with a strategy as follows: (1) eat at least 6 times per day: breakfast, morning snack, lunch, afternoon snack, dinner and evening snacks; (2) reduce fat intake ( $\leq 30 \mathrm{gr} / \mathrm{hari})$, increase your intake of carbohydrates and protein; (3) eat more than 1000 calories per day. ${ }^{4}$

In addition to the nutritional information is balanced on the age group 30-49 years and patterns a regular meal in the intervention group were also given information about how the measurements of food in household size nutritional adequacy in hopes it can be fulfilled in accordance with the his needs. In the intervention group were also given a daily diary about the eating patterns and intake required by women pramenopause every day here with the menus at intake every day. Diary entry given expected to control their intake eat a regular as well as women pramenopause it can also assess whether food consumption in excess or less intake as well as its regular pattern or not.

The results of the research conducted in the intervention group showed change of improvements towards the pattern and frequency of good eating. Health information about balanced nutrition into consideration for women in considering the pramenopause goodness and ugliness for his health, in add it again with the information they can about the trend of increased weight with increasing age. Even this material into an interesting topic for intervention and many respondents asked about weight changes growing though its a little bit even they admit often hold hunger in order not to eat a lot.

The frequency of consumption of food can illustrate how much food consumed. The respondents in this study either the intervention group and the control group mostly missed one or more meals especially breakfast. Various reasons put forward, Why skipping breakfast among them in a hurry, not hungry, keeping the weight and the unavailability of a breakfast will be in the eating.

Can be seen to gradually change the intervention group in changing the frequency of dining with regular and start not miss meal time and took myself to breakfast. Although some of the respondents have not entirely able to change the pattern and frequency of eating regularly. Required a

\section{Volume 6 Issue 7, July 2017 www.ijsr.net}




\section{International Journal of Science and Research (IJSR) \\ ISSN (Online): 2319-7064}

Index Copernicus Value (2015): 78.96 | Impact Factor (2015): 6.391

sustainable information right on the nutritional knowledge especially in women pramenopause. Further research is also needed to be done in order to know the weight changes when you keep paying attention to the principles of nutrition balanced.

Information on nutritional knowledge that includes the pattern and frequency of eating contribute to make someone pay more attention to food for meet the intake of various nutrients are balanced. A good diet can reduce even prevent nutritional problems. Even knowledge about nutrition also will enable individuals to apply nutritional information so that is expected to cause the behavior and style life in accordance with the information obtained regarding nutrition and health.

It takes great discipline in the fill out a diary entry about the patterns and the intake of food. This activity will make women self help in understanding and knowing her age in accordance with the needs of particularly about nutrition the need for a balanced diet.

Eating patterns and intake needs to be kept considering we get then the estrogen hormone production will also start dropping which is can affect the disruption of metabolism of fat, protein and so carbohydrates tendency gaining weight. Need conceived with a regular diet and intake of a balanced can maintain stable blood sugar regulation in order burn fat and lose weight. In addition to the fulfillment of a balanced nutritional meal intake and diet a regular basis, information on the consumption of Calsium $800 \mathrm{mg} /$ day and vitamin D, $5 \mu \mathrm{g} /$ day intake in eating is especially important for women who are more than 30 years. The recommended phosphorus intake was $600 \mu \mathrm{g} /$ day.

Bone health is essential for an active life, because the bone forming the body, protect organs, and can make the body move, move, standing, sitting, and other activities. The giving phytoestrogen therapy is used as a hormone in the English use when estrogen declines. Phytoestrogens is phytochemicals have oestrogenic activity. Isoflavones and lignans is a phytoestrogen compounds. In addition to the Phytoestrogens, calcium and vitamin $\mathrm{D}$ can also be automated hormone therapy. Pramenopause women's empowerment with the intervention of PEM is able to changing the perception of the individual against the vulnerability and severity of a the disease, resulting in the perception of the extent of the threat against the disease occurs against it. Consideration of the benefit will be into consideration in approving the expected behavior or no, until finally deciding on expected behavior (cues to action).

\section{Conclusion}

1) There is a difference of knowledge patterns and intake eating woman pramenopause before and after application of the Pramenopause Empowerment Model (PEM) based Health Belief Model on group the treatment and the control group.

2) There is a difference in frequency of feeding (diet) female pramenopause before and after the application of Pramenopause Empowerment Model (PEM) on treatment group and the control group.

\section{Recommendation}

1) The importance of socialization of a paperback book and diary consumption patterns of eating in the empowerment of women so that it can increase the pramenopause health and quality of life.

2) The importance of regular counselling for women by the Government in cooperation with Clinics and health care institutions in assessing the tendency the increase in weight as the impact of the decrease in estrogen production by balancing the intake of food and physical activity.

\section{References}

[1] Achie LN., Olorunshola KV., Toryila JE., Tende JA., 2012, The Body Mass Index, Waist Circumference and Blood Pressure of Postmenopausal Women in Zaria, Northern Nigeria; Current Research Journal of Biological Science, Published April 05,2012,4(3):329332.

[2] Moilanen JM, Aalto AM, Raitanen J, Hemminki E, Aro AR, Luoto R., 2012, Physical activity and change in quality of life during menopause--an 8-year follow-up study, Health and Quality of Life Outcomes BioMed Central 10:8

[3] David S.R., Branco CC., Chedraui P., Lumsden, MA., Nappi RE., Shah D., Villaseca P., 2012, Understanding weight gain at menopause, Women"s Health Research Program, Climacteric, 2012:15:419-29, Melbourne, Australia

[4] Harpaz, M.,\& Wolff, R., 2014, Menopause Reset, PT Serambi Ilmu Semesta, Cetakan I, Jakarta.

[5] Kemenkes RI, 2014, Balanced Nutrition Guidelines, Permenkes RI No.41 Tahun 2014.

[6] Depkes RI. 2003. Survey Of Body Mass Index (BMI) Collection Of Nutritional Status Of Adults Based On BMI Directorate Bina Nutrition Society

[7] Murti B., 2003. Principles And Methods Of Epidemiology Research. The Second Edition, Jilid Pertama. Yogyakarta: Gajah Mada University Press.

[8] Champion V.L., Skinner C.C., 2008, The Health Belief Model In : Health Behavior and Health Education. Theory, Research and Practice $4^{\text {th }}$, Glanz, K., Rimer, B K., Viswanath, K., E-book Jossey-Bass A Wiley Imprint.

[9] Glandz K.,Rimer B.K.,Viswanath K., 2008, Health Behavior and Health Education. Theory, Research and Practice $4^{\text {th }}$, E-book Jossey-Bass A Wiley Imprint.

[10] Hadi. H., 2003, The Double Burden Of Nutritional Problems, Http://www.gizi.net/download. pdf. Accessible 11 Desember 2012

[11] Siregar, MFG., 2015, Review Artile : Hormonal therapy for aging process in women, International Journal of Advances in Medicine, IJAM : April-June 2015 Vol.2(2):83-87

[12] Juntunen M., Niskanen L., Saarelainen J., Tuppurainen M., Saarikoski S., Honkanen R., 2003, Changes in body weight and onset of hypertension in perimenopausal women: Journal of Human Hypertension 200317 (775779)

[13] Baziad A., 2003 , Menopause and andropause. Jakarta: Yayasan Bina Pustaka Sarwono Prawirohardjo.

\section{Volume 6 Issue 7, July 2017 www.ijsr.net}




\section{International Journal of Science and Research (IJSR) \\ ISSN (Online): 2319-7064}

Index Copernicus Value (2015): 78.96 | Impact Factor (2015): 6.391

[14]Lestary D., 2010, The Ins And Outs Of Menopause. Jogjakarta: Graha Ilmu.

[15] Tan M.N., Kartal M., Guldal D., 2014, The effect of physical activity and body mass index on menopausal symptoms in Turkish women: a cross-sectional study in primary care. BMC Womens Health. 2014; 14: 38. Published online 2014 Mar 6.

[16] Kemenkes RI, 2011, National strategy for the implementation of the pattern of food consumption and physical activity to prevent infectious diseases.

[17] Kassem M.A, Meksem K., Iqbal M.J., Njiti V.N., Banz W.J., Winters T.A., Wood A., Lightfoot D.A., 2004, Definition of Soybean Genomic Regions That ontrol Seed Phytoestrogen Amounts, Jurnal of Biomedicine and Biothenology 2004: 1 (2004)52-60

Volume 6 Issue 7, July 2017 www.ijsr.net 